\title{
IDENTIFICATION AND CHARACTERISATION OF BACTEROIDES CORRODENS
}

\author{
L. R. Hill, J. J. S. Snell and S. P. Lapage \\ National Collection of Type Cultures, Central Public Health Laboratory, \\ Colindale Avenue, London
}

HeNRiksen (1948) and Holm (1950) briefly described some Gram-negative, anaerobic organisms that grew as depressed or "pitting" colonies on agar media. Eiken (1958) gave a fuller description based on 21 strains, and considered them to be a species of Bacteroides, for which he proposed the name B. corrodens. The " corroded " appearance of agar surfaces due to the depressed colonial growth was well illustrated by Reinhold (1966) and Khairat (1967). Both Eiken and Khairat considered the organism to be a strict anaerobe but, more recently, Henriksen (1969a) reported that only three strains of the 26 he studied were strict anaerobes. For this and other reasons, Henriksen questioned the suitability of classifying the organism in the genus Bacteroides.

The "corroding bacillus" may have some clinical importance. Strains have been isolated from mandibular abscesses, sputum, and a cerebral abscess (Eiken), a variety of abscesses of the respiratory tract (Reinhold), cases of bacteriaemia after dental extractions and specimens from gingival sulci (Khairat), nose and throat swabs and a neck abscess (Henriksen, 1969a). The strains to be described here were from brain and liver abscesses, a colostomy wound, tonsils, sputa, a perinephric abscess, a forehead wound due to a bite by a boy, pleural fluid in a case of carcinoma of the lung, and a nasal swab.

During the past $2 \mathrm{yr}$ we have identified eight strains as $B$. corrodens. All except one of these were found in Britain; no previous reports have been made of the isolation of this species in this country. Two strains of B. corrodens from the National Collection of Type Cultures (NCTC) were included for comparison with the newly isolated strains.

Although the ability to pit agar media is a very striking characteristic, some previous authors have reported non-pitting variants of $B$. corrodens; moreover, pitting is not an exclusive property of $B$. corrodens. None the less, whether it produces pitting or not, $B$. corrodens can be readily identified on the basis of a few biochemical tests. The purpose of the present work is to draw attention to this little-known organism and its characteristics, including the DNA-base compositions of six of the strains studied.

\section{MATERIALS AND METHODS}

Organisms. Ten strains of $B$. corrodens have been examined (table I). No. A40/68 was obtained from the pus from a brain abscess of an adolescent girl before and after her death. The post-mortem findings were bilateral frontal sinusitis, caries of the frontal bone and a

Received 15 Oct. 1969; accepted 1 Dec. 1969.

J. MED. MICROBIOL.-VOL. 3 (1970) 
large right frontal abscess. An anaerobic streptoccus was also isolated. No. A124/68 was isolated from a liver abscess at the necropsy of a 62-yr-old woman. The principal cause of death was numerous large liver abscesses following pylephlebitis. No. A8/69 was isolated, with Escherichia coli, from a suppurating colostomy wound. No. A13/69 was obtained from a diseased tonsil during an investigation of the bacterial flora of the throat. No. A58/69 was isolated in pure culture from a nose swab from an infant with otitis media and sinusitis. No. A60/69 was obtained with E. coli and Streptococcus faecalis from a perinephric abscess. No. A61/69 was isolated from a forehead wound caused by a bite from a boy; the wound yielded the normal mouth fiora in addition to B. corrodens. No. A71/69 was obtained from the pleural fluid from a 63-yr-old man who had a carcinoma of the lung.

The type culture of $B$. corrodens, NCTC10596 (Henriksen's no. 333/54-55; Henriksen, $1969 a$ and $c$ ), and NCTC10647, which both originated from sputum, were selected for comparison with the above strains.

TABLE I

Strains of Bacteroides corrodens used in the present work

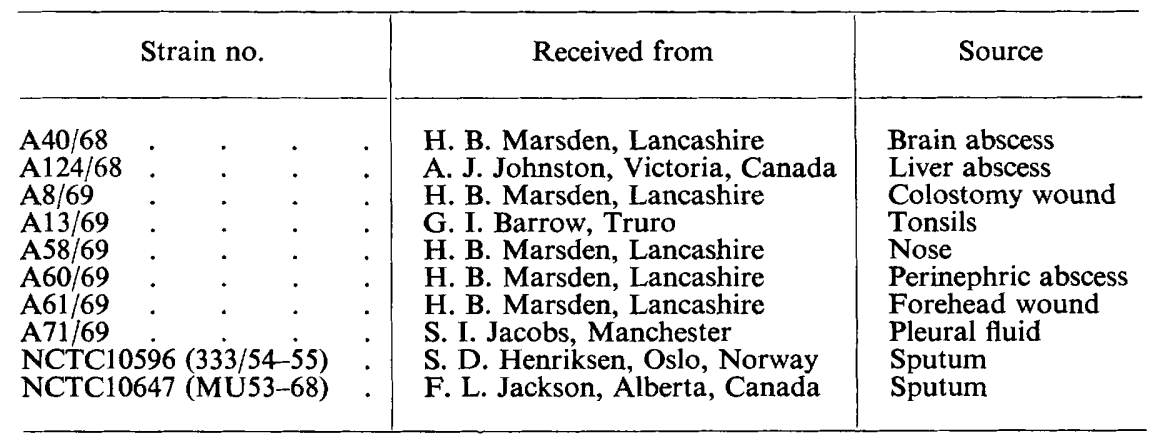

The type culture of Moraxella kingii (NCTC10529, Henriksen's no. 4177/66; Henriksen and Bøvre, 1968) was chosen to check the DNA-base composition of this species, as determined by the melting-temperature method. The base composition of this strain, as determined by the buoyant-density method, has previously been reported (Henriksen and Bøvre; Bøvre, Fiandt and Szybalski, 1969).

Bacteriological investigations. To compare growth at $37^{\circ} \mathrm{C}$ on nutrient agar and on 5 per cent. horse blood agar under various gaseous conditions, inoculated plates were incubated as follows: aerobic growth was tested in ambient air; the effect on growth of added carbon dioxide was observed after incubation in a candle jar; that the enhanced growth in the candle jar was not simply due to increased humidity was shown by incubating a culture in a similar closed jar, without the candle but with added moisture. Anaerobic growth was tested in a jar containing 95 per cent. hydrogen and 5 per cent. carbon dioxide. Growth on nutrient agar plus 0.05 per cent. cystine and on heated blood (" chocolate ") agar was tested at $37^{\circ} \mathrm{C}$ aerobically and anaerobically.

The strains were examined microscopically after 48 hours' incubation of blood-agar cultures.

Biochemical tests were carried out as described previously (Lapage, Hill and Reeve, 1968; Midgley et al., 1970), mainly by the methods of Cowan and Steel (1965, pp. 150-165). Antibiotic sensitivities were tested by means of nutrient agar plates incorporating twofold dilutions, within the range $6 \cdot 25-0 \cdot 19 \mu \mathrm{g}$ per ml final concentrations, of the following antibiotics: ampicillin, tetracycline, streptomycin, erythromycin, chloramphenicol and penicillin.

DNA extraction. Cells for DNA extraction were obtained from the growth as a lawn culture of each strain on blood agar in Roux bottles; two or three bottles were needed for each strain. The cells were harvested with $0 \cdot 15 \mathrm{M}-\mathrm{NaCl}+0 \cdot 1 \mathrm{M}$ ethylene-diamine-tetraacetic acid (EDTA), $p \mathrm{H} 8 \cdot 0$, within 7 days' aerobic incubation. Subcultures were made 
from the cells after they had been packed by centrifugation to detect possible contamination. The method of Marmur (1961) was used to extract and purify the DNA, the initial cell lysis being achieved satisfactorily by the addition of sodium lauryl sulphate at a final concentration of 2 per cent. (w/v), followed by heating to $60^{\circ} \mathrm{C}$ for $15 \mathrm{~min}$. The purified DNA fibres were finally dissolved in $0 \cdot 1 \mathrm{M}-\mathrm{NaCl}+0 \cdot 01 \mathrm{M}$ phosphate at $p \mathrm{H} 7 \cdot 0$.

Determination of DNA-base composition. By the use of the apparatus previously described (Hill, 1968), the DNA melting temperatures (Tm) were determined in the above salinephosphate buffer, by the method of Marmur and Doty (1962). The equation relating Tm to per cent. guanine + cytosine/total bases (per cent. GC) for this buffer was calculated from the general equation of Owen, Hill and Lapage (1969) and was found to be

$$
\text { per cent. } \mathrm{GC}=2 \cdot 352 \mathrm{Tm}-153 \cdot 49 .
$$

This equation was checked by determining the Tm values of the three previously assayed DNA samples from: Micrococcus lysodeikticus, 72.05 per cent. GC; Escherichia coli, 50.50 per cent. GC; and Staphylococcus saprophyticus, 33.35 per cent. GC (Owen et al.). The experimental equation was:

$$
\text { per cent. GC }=2 \cdot 362 \mathrm{Tm}-155 \cdot 32 \text {. }
$$

Equation (2) was used to calculate the base compositions reported here. However, use of the two equations gives a difference in calculated per cent. GC values of less than 1 per cent. GC.

\section{RESULTS}

Microscopically, all ten strains of $B$. corrodens appeared as Gram-negative oval and rod-shaped organisms, approximately $0.5-0.75 \mu \mathrm{m}$ wide and 1.0 $3.0 \mu \mathrm{m}$ long. They were non-motile when examined by the hanging-drop method.

When first received in the laboratory, all the strains except A124/68 grew poorly aerobically, but growth was better in a candle jar and under anaerobic conditions with additional $\mathrm{CO}_{2}$. Unfortunately no comparisons were made with growth in a moist jar without $\mathrm{CO}_{2}$ on first reception, therefore it cannot be stated whether $\mathrm{CO}_{2}$ improved growth. In a later comparative study, after the strains had been grown on artificial media for several subcultures, no improvement was noted with added $\mathrm{CO}_{2}$ on either nutrient or blood agar. However, growth on 5 per cent. blood agar was better than that on nutrient agar both aerobically and in $\mathrm{CO}_{2}$. Additional moisture did not improve growth. Anaerobic growth was equally good on nutrient and on blood agar. Growth was no better on chocolate agar than on blood agar, nor did the addition of cystine to nutrient agar improve growth, aerobically or anaerobically. The strains were non-haemolytic on blood agar. All the strains grew at $30^{\circ} \mathrm{C}$ and $37^{\circ} \mathrm{C}$, but only one, NCTC10596, grew also at $22^{\circ} \mathrm{C}$.

Most of the strains produced pitting on nutrient agar and on blood agar, generally more marked on the latter medium (table II). However, strain A40/68 did not show pitting on either medium, strain A60/69 showed pitting only on blood agar, and strain A124/68 showed slight pitting on nutrient agar but none on blood agar. Strain A71/69 produced pitting and non-pitting variants, which could be separated into pure forms by subculture; biochemically, the "smooth" and " rough" variants of this strain were identical. Pitting colonies had exactly the appearance shown in the illustrations of Khairat. 
The biochemical results are summarised in table III. All strains were catalase-negative, and were oxidase-positive when tested by Kovács' (1956)

TABLE II

Cultural characters of Bacteroides corrodens

\begin{tabular}{|c|c|c|}
\hline General & \multicolumn{2}{|c|}{$\begin{array}{l}\text { Gram-negative ovals and rods, non-motile, growing at } 30^{\circ} \mathrm{C} \\
\text { and } 37^{\circ} \mathrm{C} \text {, aerobically and anaerobically. Growth poor on } \\
\text { plain and cystine-enriched nutrient agar (except anaerobically), } \\
\text { improved on blood or chocolate agar. May prefer } \mathrm{CO}_{2} \text {-enriched } \\
\text { atmosphere or anaerobic conditions on primary isolation }\end{array}$} \\
\hline \multirow{2}{*}{ Strain no. } & \multicolumn{2}{|c|}{ Pitting on } \\
\hline & nutrient agar & blood agar \\
\hline $\begin{array}{l}\text { A40/68. } \\
\text { A124/68 } \\
\text { A8/69. } \\
\text { A13/69. } \\
\text { A58/69. } \\
\text { A60/69. } \\
\text { A61/69. } \\
\text { A71/69 " smooth : } \\
\text { "rough" } \\
\text { NCTC10596 } \\
\text { NCTC10647 }\end{array}$ & $\begin{array}{l}- \\
\pm \\
+ \\
+ \\
\pm \\
\pm \\
\pm \\
+ \\
+ \\
+ \\
+\end{array}$ & $\begin{array}{l}- \\
+ \\
+ \\
+ \\
+ \\
+ \\
+ \\
+ \\
+ \\
+ \\
+\end{array}$ \\
\hline \multicolumn{3}{|c|}{$\begin{array}{c}-=\text { No pitting; } \pm=\text { slight pitting; }+=\text { marked pitting. } \\
\text { TABLE III } \\
\text { Biochemical characters of Bacteroides corrodens }\end{array}$} \\
\hline
\end{tabular}

\begin{tabular}{|c|c|c|c|}
\hline Tests positive & & & s negative \\
\hline  & & $\begin{array}{l}\text { Production of: } \\
\text { catalase } \\
\text { caseinase } \\
\text { arginine dihydrolase } \\
\text { urease } \\
\beta \text {-galactosidase } \\
\text { acid from glucose } \\
\text { indole } \\
\mathrm{H}_{2} \mathrm{~S} \\
\text { acetoin } \\
\text { Methyl red }\end{array}$ & $\begin{array}{l}\text { Gluconate conversion } \\
\text { Starch hydrolysis } \\
\text { Oxidation/Fermentation } \\
\text { Purple milk } \\
\text { Citrate utilisation } \\
\text { Growth in KCN } \\
\text { Liquefaction of: } \\
\text { gelatin } \\
\text { serum } \\
\text { Haemolysis on blood agar } \\
\text { Opalescence on egg-yolk agar }\end{array}$ \\
\hline
\end{tabular}

method. Reduction of nitrate to nitrite by all strains was demonstrable by the Griess-Ilosvay method, but in tests by Cook's (1950) method two strains failed to reduce nitrate (A58/69 and A71/69). In Møller's (1955) media, the strains did not produce a dihydrolase for arginine, but did produce decarboxylases for lysine and ornithine, except for strain A124/68, which produced 
decarboxylase for lysine only. All strains were sensitive to the following antibiotics at the concentrations indicated: ampicillin $(1.56 \mu \mathrm{g}$ per $\mathrm{ml})$, tetracycline (3.125 $\mu \mathrm{g}$ per $\mathrm{ml})$, streptomycin $(6.25 \mu \mathrm{g}$ per $\mathrm{ml})$, erythromycin $(6.25 \mu \mathrm{g}$ per $\mathrm{ml})$, chloramphenicol (1.56 $\mu \mathrm{g}$ per $\mathrm{ml})$, penicillin (3.125 IU per $\mathrm{ml})$.

None of the strains grew in Koser's citrate or in the presence of KCN. Indole, $\mathrm{H}_{2} \mathrm{~S}$, and acetoin were not produced and the methyl red and $\beta$-galactosidase tests were negative. Neither gelatin nor Loeffler's serum slopes were liquefied. Gluconate was not oxidised, and neither starch nor casein was

TABLE IV

DNA-base compositions of Bacteroides corrodens and genera of the family Brucellaceae

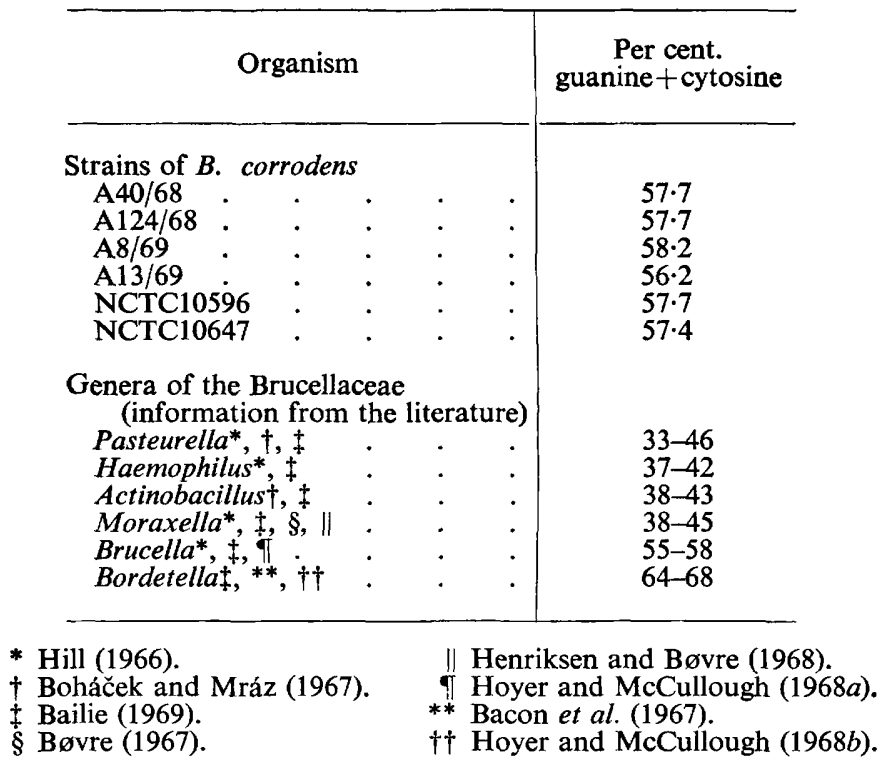

hydrolysed. Urease was not detected on Christensen's medium. Growth but no opalescence was obtained on egg-yolk agar. No change was produced in purple milk or in the Hugh and Leifson (1953) oxidation-fermentation (O-F) medium with glucose as substrate. Acid was not produced from glucose in peptone-water media, serum-water media, or on Thompson and Knudsen's (1958) medium for neisserias (see Cowan and Steel, pp. 108-110). Only two strains grew on MacConkey's agar.

The DNA-base compositions of the six strains of $B$. corrodens examined were similar to each other (table IV), the range being $56 \cdot 2-58 \cdot 2$ per cent. GC. The maximum difference in melting temperatures was $0.85^{\circ} \mathrm{C}$ which is about five times the experimental reproducibility of the melting-temperature method under our conditions $\left( \pm 0 \cdot 157^{\circ} \mathrm{C}\right.$, Owen et al. $)$. The DNA extracted from Moraxella kingii had a base composition significantly different from that of B. corrodens; the Tm was $86 \cdot 5^{\circ} \mathrm{C}$ and the per cent. GC was $49 \cdot 0$. The DNAbase composition of this same strain determined by Henriksen and Bøvre 
and by Bøvre et al. was 44.5 per cent. GC \{or 45.4 per cent. if the original equation of Schildkraut, Marmur and Doty (1962) is used to calculate per cent. $\mathrm{GC}$ from the given buoyant-density measure\}. Differences of this magnitude, 4.5 per cent. GC, in values derived from melting-temperature and buoyantdensity measures are not unexpected, since both values are derived from empirical equations.

\section{DisCUSSION}

With the exception of the gaseous requirements, the characters of the ten strains studied here corresponded well to those given by Eiken (1958), Reinhold (1966), Khairat (1967), and Henriksen (1969a). The strains form a very homogeneous group and include the type strain of $B$. corrodens.

Our results confirm Henriksen's (1969a) finding that this species is not a strict anaerobe. Our experience was that the strains on first isolation prefer anaerobic conditions (i.e., 95 per cent. $\mathrm{H}_{2}$ and 5 per cent. $\mathrm{CO}_{2}$ atmosphere) or a carbon dioxide-enriched atmosphere, but that this preference is readily lost on subculture in the laboratory. Dr F. L. Jackson (personal communication) is of the opinion that there are two groups of $B$. corrodens: facultative anaerobes and strict anaerobes. We have not encountered any strains of the latter type, but the former correspond to those we have studied:

We found that, when tested with the tetramethyl-p-phenylenediamine reagent, $B$. corrodens was oxidase-positive. Khairat, who did not specify the reagent he used, reported his strains to be oxidase-negative. Henriksen (1969a), using the tetramethyl reagent, found his strains to be positive and speculated that if Khairat had used the dimethyl reagent, weak positive reactions may have been recorded as negative.

The finding, not previously reported, that $B$. corrodens produces decarboxylases for lysine and ornithine, but no dihydrolase for arginine, is of value for the identification of this species. These reactions provide, in addition to nitrate reduction, additional positive characters for this species, which is otherwise biochemically very inactive.

The close phenotypic similarity of the strains to each other is also reflected in the very similar DNA-base compositions found (56.2-58.2 per cent. GC) for all six of the cultures tested. This suggests that these strains may be closely related genotypically.

Moraxella kingii resembles $B$. corrodens in some characters, especially in that it too possesses the unusual combination of being catalase-negative and oxidase-positive (Henriksen, 1969b). For this reason we thought it worth while to check the DNA-base composition of $M$. kingii by our meltingtemperature method. The value obtained, 49 per cent. GC, is in reasonable agreement with the value previously derived from buoyant-density measures (Henriksen and Bøvre, 1968), and is sufficiently different from the values obtained for $B$. corrodens to exclude the possibility that these two species are genetically related.

The taxonomic position of $B$. corrodens is uncertain. Henriksen (1969a) considered that it should be excluded from the genus Bacteroides on the grounds 
of its microscopical morphology and ability to grow aerobically, and suggested that it might belong to the Brucellaceae. However, the family Brucellaceae consists of a very heterogeneous group of organisms; this is well illustrated by the wide range of per cent. GC values found in its members (table IV). The only per cent. GC values close to those of $B$. corrodens are 55-58 per cent. $\mathrm{GC}$ for Brucella spp. In many of the usual bacteriological tests the results given by $B$. corrodens and by Brucella spp. would be negative. Superficially,

TABLE V

Differentiation of Bacteroides corrodens

\begin{tabular}{|c|c|c|c|c|c|}
\hline \multirow[b]{2}{*}{ Test } & \multicolumn{5}{|c|}{ Results of the stated tests on } \\
\hline & $\begin{array}{l}\text { Bacteroides } \\
\text { corrodens } \\
\text { (10 strains) }\end{array}$ & $\begin{array}{c}\text { Brucella } \\
\text { spp.* } \\
\text { (38 strains) }\end{array}$ & $\begin{array}{c}\text { Cardiobacterium } \\
\text { hominis } \dagger \\
\text { (2 strains) }\end{array}$ & $\begin{array}{c}\text { Moraxella } \\
\text { kingii }^{*} \\
\text { (1 strain) }\end{array}$ & $\begin{array}{c}\text { Other } \\
\text { Moraxella spp. }{ }^{*} \\
\text { (12 strains) }\end{array}$ \\
\hline $\begin{array}{l}\text { Production of: } \\
\text { indole } \\
\text { acid from carbohydrates } \\
\text { catalase } \\
\text { oxidase }: \\
\text { urease } \\
\text { arginine dihydrolase } \\
\text { lysine decarboxylase. } \\
\text { ornithine decarboxylase } \\
\begin{array}{l}\text { Nitrate reduction } \\
\text { Oxidation/fermentation }(\mathrm{O}-\dot{\mathrm{F}})\end{array}\end{array}$ & $\begin{array}{l}- \\
\overline{-} \\
\overline{+} \\
\pm \\
\overline{+} \\
+ \\
+ \\
+ \\
\text { nil }\end{array}$ & $\begin{array}{c}- \\
\overline{-} \\
\overline{\mathrm{d}} \\
+ \\
\pm \\
\bar{\mp} \\
\overline{-} \\
+ \\
\text { nil }\end{array}$ & $\begin{array}{l}+ \\
+ \\
\bar{t} \\
\pm \\
\pm \\
- \\
- \\
\overline{\mathbf{F}}\end{array}$ & $\begin{array}{l}- \\
+ \\
+ \\
+ \\
- \\
- \\
= \\
+ \\
F\end{array}$ & $\begin{array}{c}- \\
\overline{-} \\
+ \\
+ \\
\overline{-} \\
\overline{-} \\
\overline{\mathrm{d}} \\
\text { nil or } \\
\text { no growth }\end{array}$ \\
\hline $\begin{array}{l}\text { DNA: per cent. } \\
\text { guanine+cytosine }\end{array}$ & $56-58$ & $55-58 \$$ & $61 \cdot 7 \pi$ & $44 \cdot 5-49 \S$ & $40-45 \|$ \\
\hline
\end{tabular}

$+=$ Positive result with all strains; $-=$ negative result with all strains; $\mp=$ usually negative, but late positive reaction with a few strains; $\mathrm{d}=$ some reactions positive, some negative. In $\mathrm{O} / \mathrm{F}$ tests: nil = growth with no acidification in either tube; $F=$ fermentation.

* Brucella abortus, melitensis, and suis: from NCTC records; $\dagger$ from Midgley et al. (1970); $\$$ see table IV; $\S$ from Bøvre et al. (1969) and this paper; \| from Bøvre et al. (1969); If from Hill et al., unpublished.

however, B. corrodens does not appear to resemble Brucella spp., but a comparative study of these species, including serological tests, has not been carried out.

It seems to be premature to make any decision about the taxonomic position of $B$. corrodens for the reasons given above and because of the uncertain state of the classification of the genus Bacteroides at the present time, and the paucity of information about the DNA-base compositions of the species of this genus.

Finally, the identification of $B$. corrodens is readily made by its typical pitting colonial morphology when this characteristic is present, and in its absence by the results of a few common tests: catalase-negative, oxidase-positive, nitrates reduced to nitrites, arginine dihydrolase-negative, lysine and ornithine decarboxylases-positive; otherwise biochemically inert, especially in not producing acid from carbohydrates. A set of tests is given in table $\mathrm{V}$ that is 
sufficient to differentiate $B$. corrodens from Brucella spp., Moraxella kingii, other Moraxella spp. and Cardiobacterium hominis.

Two further strains of $B$. corrodens have recently been identified. Their characters were similar to those of the strains described above, and they were both facultative anaerobes. One was isolated from a finger abscess, the other from a subphrenic abscess.

\section{SUMMARY}

Eight recently isolated strains of Bacteroides corrodens, seven of which originated in Britain, were compared with two strains of this species from the National Collection of Type Cultures.

The principal characteristics of $B$. corrodens were: Gram-negative, nonmotile ovals and rods; usually grows as depressed or pitting colonies on agar media, but also produces non-pitting variants; prefers $\mathrm{CO}_{2}$-enriched atmospheres or anaerobic conditions on primary isolation, but becomes a facultative anaerobe on subculture in the laboratory; catalase-negative; oxidase-positive; nitrate reduced to nitrite; arginine dihydrolase not produced, lysine and ornithine decarboxylase produced; acid not produced from carbohydrates; otherwise biochemically inert.

The DNA-base composition was determined by the melting-temperature method and was found to range from $56 \cdot 2$ to $58 \cdot 2$ per cent. GC.

We thank Drs G. I. Barrow, H. B. Marsden, F. L. Jackson, S. I. Jacobs, and A. J. Johnston for sending us strains of $B$. corrodens and details of their isolation. We also thank Dr F. L. Jackson for allowing us to see his manuscript in preparation and for very helpful comments. A preliminary account of this work was presented at the Conference on the Taxonomy of Bacteria, Brno, Czechoslovakia, September 1969. This work was partly supported by grant number G966/60/13 from the Medical Research Council.

\section{REFERENCES}

Bacon, M. F., Overend, W. G., Lloyd, 1967. Archs Biochem. Biophys., 118, 352.

P. H., AND PeACOCKe, A. R.

BaILIE, W. E.

BOHÁČEK, J., AND MRÁz, O.

BøVRe, K.

Bøvre, K., Fiandt, M., and Szybalski, W.

CoOK, G. T.

Cowan, S. T., AND Steel, K. J.

EIKEN, M.

HENRIKSEN, S. D.

"

,

HeNriksen, S. D., AND Bøvre, K.

HrLL, L. R. .

Holm, P. .
1969. Ph.D. Thesis, Kansas State University.

1967. Zentbl. Bakt., Abt. I, Orig., 202, 468.

1967. Acta path. microbiol. scand., 69, 123.

1969. Canad. J. Microbiol., 15, 335.

1950. J. Clin. Path., 3, 359.

1965. Manual for the identification of medical bacteria, London.

1958. Acta path. microbiol. scand., 43, 404.

1948. Ibid., 25, 368.

1969a. Ibid., 75, 91.

1969b. Ibid., 75, 85 .

1969c. Int. J. System. Bact., 19, 165.

1968. J. Gen. Microbiol., 51, 377.

1966. Ibid., 44, 419.

1968. In Identification methods for microbiologists, part B, ed. by B. M. Gibbs and D. A. Shapton, London, p. 177.

1950. Acta path. microbiol. scand., 27, 736. 
Hoyer, B. H., AND McCullough, N. B. 1968a. J. Bact., 95, 444.

" " , " " 1968b. Ibid., 96, 1783.

Hugh, R., ANd LeIfSON, E. . ” . . 1953. Ibid., 66, 24.

Khatrat, O. . . . . . . . 1967. J. Path. Bact., 94, 29.

Kovács, N. . . . . . . . 1956. Nature, Lond., 178, 703.

LaPage, S. P., Hill, L. R., AND Reeve, 1968. J. Med. Microbiol., 1, 195. JEANNE D.

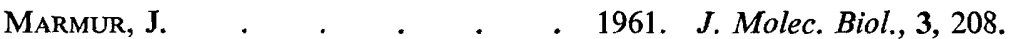

MARMUR, J., AND DotY, P. . . . . 1962. Ibid., 5, 109.

Mmgley, Jenifer, LaPage, S. P., Jen- 1970. J. Med. Microbiol., 3, 91. KINS, B. A. G., BARROW, G. I., ROBERTS, M. E., AND BUCK, A. G.

MøLLER, V.

1955. Acta path. microbiol. scand., 36, 158.

OWen, R. J., Hill, L. R., AND LAPAGE, 1969. Biopolymers, 7, 503. S. P.

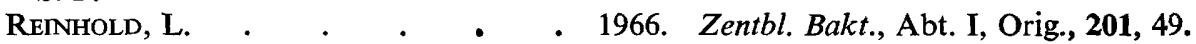

Schildkraut, C. L., Marmur, J., AND 1962. J. Molec. Biol., 4, 430.

DOTY, P.

Thompson, R. E. M., ANd KNudsen, A. 1958. J. Path. Bact., 76, 501. 